\title{
Effects of Economic Globalization on Environment
}

\author{
FAZIL KAYIKÇI \\ Yıldız Technical University Department of Economics \\ Email: fkayikci@yildiz.edu.tr \\ Tel: +902123836818
}

\begin{abstract}
Competition of countries for the sake of growth and development has caused to depletion of natural resources without any planning. With the economic development and mostly globalization, environmental degradation has exceeded the national borders. Many countries perceived that globalization would open a window to have access to more capital flows, technology, cheaper imports, and larger export markets. But these countries did not have any idea that the benefits of increased efficiency will not go to all countries equally. In this paper, the effects of globalization on the environment and sustainability are analyzed by considering its economic costs in different types of environmental degradation. And then, discussion is provided how the negative impacts can be minimized and the positive impacts can be maximized with presenting the theory of Environmental Kuznets Curve. However, it is noticed that the aim is not to reduce pollution damages to zero but reduce them to socially optimal levels. This optimal level is obtained where the marginal social benefit of the decreasing of the pollution equals the marginal social costs of the efforts to reduce pollution.
\end{abstract}

Keywords: Globalization, Environment, Degradation, Growth, Development.

\section{Introduction}

Environmental problems were one of the most controversial subjects at last decades. Competition of countries for the sake of growth and development has caused to depletion of natural resources without any planning. However, we cannot bound the environmental problems to the last decades; those problems have been the subject of human being for a long time, today this problem attain new dimensions both quantitatively and qualitatively. With the economic development and mostly globalization, environmental degradation has exceeded the national borders.

Globalization, which was used infrequently before the 1990s, is now in common parlance. It refers primarily to an economic system in which raw materials, manufactured goods, intellectual property and financial transactions flow freely (although not equally) across international borders under the supervision only of an international trade authority. It also refers to the homogenization of language and cultural identity that accompanies this flux of material, ideas and money. Despite its growing strength, the side effects of this pervasive economic strategy remain poorly understood, perhaps because the great majority of them are indirect. This is especially true for the environmental effects (Ehrenfeld, 2003).

Economic globalization is perceived as an historical process of increasing integration of economies around the world through trade, financial flows, movement of people (labor) and knowledge (technology) across international borders. The term has come into common usage since the 1980s. At that time many countries visualized globalization as an opportunity to explore their ability to integrate with the global market. It was 
thought that global markets offer greater opportunity for people to tap into more and larger markets around the world. Many countries perceived that globalization would open a window to have access to more capital flows, technology, cheaper imports, and larger export markets. But these countries did not have any idea that the benefits of increased efficiency will not go to all countries equally. Moreover, it was not easy for most of these countries to apprehend clearly that they must be prepared to embrace the policies needed, and in the case of the poorest countries, they may need the support of the international community (Salahuddin, 2005).

In this paper I will try to reveal the effects of globalization on the environment. I will try to discover the facts from economic perspective. In the first section I introduced the subject and I continued with the description of the globalization. In the second section, I presented the view of globalization about the environment. In the third section, I tried to reveal the effects of globalization on the environment and sustainability by considering its economic costs in different types of environmental degradation. And then, I discussed how the negative impacts can be minimized and the positive impacts can be maximized with presenting the theory of Environmental Kuznets Curve. After that the paper continued with the effects of environment on the globalization. In the sixth section, I gave some points in order to protect environment by managing globalization and the outputs of the globalization as well. And in the last section, I tried to make some conclusions about the effects of the globalization on the environment and what can the protective activities be.

\section{Global economic thought and its environmental view}

Today's mainstream economic thought is defined as a science for the efficient utilization of scarce goods. But, the goods are only conceived as market commodities. The effects of the economic activities on ecological scarcities and nonrenewable resource degradation are beyond the view of this economic thought. Economic development needs to be planned so as to include factors such as water resources and their distribution, availability of clean water, rationing and conservation of nonrenewable resources, disposal of wastes, and effects on population and environment associated with the specific locations chosen for industrial projects. However, capitalist economies are only interested in profit maximization and economic growth at any cost including the exploitation of the vast majority of the world's resources and population. This means rapid absorption of energy and materials and the dumping of more wastes into the environment and widening environmental degradation (Foster, 2002). "The fact that the economic process continually depends on the natural world for both the generation of raw material inputs and absorption of waste outputs is simply taken for granted. More specifically, natural ecosystems are viewed simply as a gift of nature ready to be exploited by humans and in strict accordance to the laws of demand and supply." (Hussen, 2004: 15).

Beside the Neoclassical economics, which sees no apparent limits to natural resources and economic growth because of the factor substitution and technological improvement assumptions, we have to reshape the economic theory from an environmental and sustainability perspectives by focusing on qualitative economic growth where natural ecosystem is nongrowing relative to the scale of economic activity. We should protect the rights of future generations and also other elements of nature such as animals, trees etc. for their own sake. For example, "Saudi Arabia cannot simply pump more oil at any price just to raise the standard of living of the current generation because the extraction rates of the country's petroleum deposits are determined in such a way as to maximize the present value of the rent from the intertemporal use of its total petroleum deposits." (Sisay, 2005: 273)

\section{Economic costs of environmental degradation}

Capitalism and its practices with globalization do not consider the environmental consequences of their views and practices as we mentioned above. Now, we are going to see what can be done if we consider the ecological problems and try to provide sustainable development, why and in what ways today's economic 
system and globalization causes environmental degradation and pollution, what are the types of those degradations and their costs to the society and nature in an economic sense.

\section{Sustainable Development}

Sustainable development can be defined as "restricting the resource using economic activities in order to maintain population/resource stocks within upper and lower bounds regarded consistent with ecosystem stability and resilience". (Alauddin, 2004: 253) Against the global economic theories and their applications, this approach takes depletion of natural resources and damages caused by pollution into account when evaluating welfare of the society. It implies minimizing the material and energy intensity of goods and services, enhancing recyclability and the use of renewable resources. Some possible rules for sustainability are;

i) Renewable resources, such as forests or fisheries should only be exploited at or below their rates of renewal.

ii) Wastes should only be generated at or below the rates at which they can be absorbed by the assimilative capacity of the environment.

iii) Non-renewable resources should not be exploited beyond the rate at which the stock of these resources can be substituted for by renewable resources or effectively enhanced by technological progress and recycling.

iv) Ecological functions and the provision of amenity and living space should be protected, thus maintaining the carrying capacity of the environment. (Hodge, 1995: 55)

Nelder summarizes this as "A golden rule for the regeneration of the economy; leave the world better than you find it, do not take more than you need, try not to give any damage to the environment and life, and if you do this, compensate." (Nelder, 1995: 22)

\section{Market Failure and Globalization as Causes of Pollution}

In general, there are two major sources of market failures which are relevant to the problem of environmental pollution. First one is the lack of a well defined and enforceable system of private property rights in many of the environmental resources. Private economic decision makers are not receiving the correct signals concerning the use of these resources. The second is the public good nature of many environmental services. Private markets will fail to allocate sufficient resources to the production of such goods, resulting in a misallocation of resources.

We know that globalization means a new, interconnected, interdependent and unified world, in which everyone and everybody is in a close proximity to his or her fellow neighbors scattered all over the world, sharing with them life and density in spite of their different ethnical and cultural origins. Thus, it contains some sub concepts which can be considered as causes of the environmental degradation; faster urbanization, industrialization, population growth and economic growth.

Fast urbanization, which can be the result of economical, political, sociological and technological reasons, is one of the most important sub concepts of globalization that deteriorates the environment and nature. Disordered constructions and shanties, inadequate infrastructure, noise, traffic, air pollution, water pollution, solid wastes are the environmental effects of the fast urbanization process. Moreover, fast population growth causes the overuse of the natural resources and decreases their efficiency.

Industrialization is another factor for the environmental problems. Energy sector is the leading one for producing pollution and industrial countries are the leaders of using and producing energy. Most important reason for the climate change in the world is the energy production that depends on the fossil fuels. Considerable amount of air pollution is seen in the areas where industrial factories are located. Also, 
industrial wastes pollute water and agricultural land, thus decrease the variety and amount of agricultural products.

\section{Types of Pollution}

The principal types of environmental pollution and depletion are; exhaustion of nonrenewable and slowly renewable resources and global climate change, global warming, destruction of the ozone layer, removal of tropical forests, over fishing, extinction of species, loss of genetic diversity, desertification, shrinking water supplies, lack of clean water and radioactive contamination. We can briefly mention some of the important effects of environmental degradation as;

\section{Reduced Genetic Diversity in Agriculture}

A profound reduction of genetic diversity in agriculture is now underway. The process has been well documented for food plants, and pertains to vegetables, grains and tree crops. It is likely that losses of noncommercial varieties maintained by individual farmers, especially in Third World countries, are even greater, as representatives of giant seed corporations reach more and more agricultural areas that have been hitherto isolated from global trade.

The impacts of globalization are being experienced not only by domesticated varieties but by wild relatives of food plants. The wild relatives of cereals, vegetables, fruits, nuts and other crops constitute a critical resource for genes affecting disease resistance, pest resistance, yield, vigour, environmental adaptations, high starch content, soluble solids, vitamins, cytoplasmic male sterility, petaloid male sterility and harvest and transport adaptations. Many of these wild relatives are highly endemic, and their ranges are decreasing sharply because of development, overgrazing, increased herbicide use, logging and conversion of marginal lands to production and export agriculture; all of them related at least in part to globalization (Ehrenfeld, 2003: 101)

\section{Loss of Wild Species}
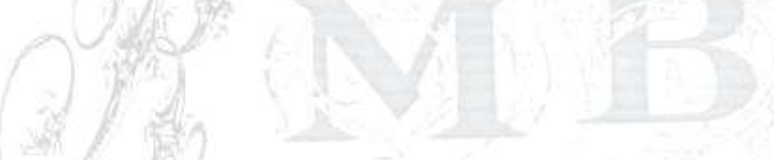

It is not possible to define the particular effect of globalization to the current extinction rate, or even to separate globalization from other, interrelated factors such as human population growth. But it is easy to understand that globalization causes huge reduction in biodiversity. Globalization affects the wild animal populations and plant populations by destroying the living areas of the species for production and trade, including increased logging, land clearing for production agriculture, over fishing of marine fisheries, roadbuilding mining and dam construction; secondary effects of pollution from production agriculture, fish farming, vehicles burning fossil fuel, added electricity generation, nuclear wastes and other sources; tertiary effects of climatic change from excess carbon dioxide, methane, fluorocarbons and other chemicals; adverse effects of ecotourism on wild flora and fauna; and the impact of the soaring numbers of exotic species, carried by the tremendous plane, ship, rail and truck traffic of global trade, on local flora and fauna (Mabogunje, 2002: 8).

\section{Deforestation}

Mostly in developing countries, burning forests for the construction and agricultural production or cutting trees for obtaining wood give high damages to the forests. Furthermore, this deforestation causes erosion problem in those countries. For example, "in sub-Saharan Africa, 52 percent of energy supply is obtained from woods. However, Japan imports woods even though 60 percent of its territories are forests. Because Japans are aware of the fact that the economic value of their forests are much higher than they can obtain from wood." (Çınar, 2003: 51) 
Air, water and soil pollution have increased markedly as global trade has increased. For example, in Taiwan, exports have soared as a result of global trade: forests have been cleared for industrial development and tree farms, soil and water have been polluted by pesticides and fertilizer, and 90,000 factories dump their wastes into air and waterways (Ehrenfeld, 2003: 100).

\section{Costs of Pollution}

Instead of dynamic optimization, static solutions and neglecting future generations play an important role in causing environmental problems. Because of these kinds of economic decisions, environmental quality decreased sharply when production and consumption increases in all over the world. Hence, environmental quality and clean environment become a scarce resource and an economic good today (Dura, 1991: 70).

Environment performs valuable services for the economy by dispensing, storing and assimilating the residuals generated as a by product of economic activity. It provides a hospitable habitat for human being and other living creatures. Certain parts of the environment are suitable for vacation. Also, environment serves as a source of materials inputs to the economy.

Costs of environmental degradation firstly start with the forgone use of environment's above mentioned and other side benefits. Beside this, cost of cleaning and external cost of pollution are also important; when we direct some funds to the cleaning of environment, we have to give up from some profitable projects; opportunity cost of purchases for cleaning are higher than actual costs. Furthermore, if the employment generating feature of those forgone investments is high enough, it may cause unemployment. In a research of Repetto and others, they estimate that Indonesia's GDP growth decreases from $7.1 \%$ to $4 \%$ between 1971 and 1984 because of deterioration in three natural resources: land, forests and petroleum (Repetto et. al., 1991).

\section{Globalization and the Environment}

The environmental impact of globalization is highly controversial. Opponents argue that globalization poses a serious challenge to the regulatory authority of national governments because multinational companies can exploit differences between the environmental regulations of individual nation states. These opponents also suggest that footloose multinational companies use global strategies to relocate polluting activities in their value chains to subsidiaries or suppliers in countries with lax environmental regulations. This threat of 'industrial flight' is presumed to increase the power of multinational companies relative to national governments. Some less-developed countries might even be tempted to use lax environmental regulations and law enforcement to provide the most polluting multinational companies with cheap production and export platforms - turning themselves into 'pollution havens. According to this view, nation states compete with one another to become the low-cost location for multinational companies investment, creating a 'race to the bottom' in which competing countries are caught in a downward spiral of lower and lower environmental regulations (Taylor, 2002: 122).

Vary famous letter about the view of the globalization and capitalism about the environmental problems and the race to the bottom effect will be helpful for understanding the situation more clearly. On December 12 1991, Lawrence Summers, Chief Economist of the World Bank, sent a memorandum to his colleagues which presents views of the orthodox economists on the environment but are seldom offered up for public scrutiny;

"Just between you and me, shouldn't the World Bank be encouraging more migration of the dirty industries to the LDCs [Less Developed Countries]? I can think of three reasons:

1) The measurements of the costs of health impairing pollution depend on the foregone earnings from increased morbidity and mortality. From this point of view a given amount of health impairing pollution 
should be done in the country with the lowest cost, which will be the country with the lowest wages. I think the economic logic behind dumping a load of toxic waste in the lowest wage country is impeccable and we should face up to that.

2) The costs of pollution are likely to be non-linear as the initial increments of pollution probably have very low cost. I've always though that under-populated countries in Africa are vastly under-polluted, their air quality is probably vastly inefficiently low compared to Los Angeles or Mexico City. Only the lamentable facts that so much pollution is generated by non-tradable industries (transport, electrical generation) and that the unit transport costs of solid waste are so high prevent world welfare enhancing trade in air pollution and waste.

3) The demand for a clean environment for aesthetic and health reasons is likely to have very high income elasticity. The concern over an agent that causes a one in a million change in the odds of prostrate cancer is obviously going to be much higher in a country where people survive to get prostrate cancer than in a country where under 5 mortality is is 200 per thousand. Also, much of the concern over industrial atmosphere discharge is about visibility impairing particulates. These discharges may have very little direct health impact. Clearly trade in goods that embody aesthetic pollution concerns could be welfare enhancing. While production is mobile the consumption of pretty air is a non-tradable. The problem with the arguments against all of these proposals for more pollution in LDCs (intrinsic rights to certain goods, moral reasons, social concerns, lack of adequate markets, etc.) could be turned around and used more or less effectively against every Bank proposal for liberalization.” (Foster, 2002: 61).

When we analyze the memorandum, first we see that the lives of individuals in the third world, which are measured by forgone earnings from illness and death, are worth less than that of individuals in the advanced capitalist countries where wages are often hundreds of times higher. Second, clean environment is viewed as a luxury good pursued by rich countries with high life expectancies where higher aesthetic and health standards apply; cost of production in the world therefore will fall if polluting industries are shifted from the center to the periphery of the world. "Summers argument for dumping toxic wastes in the third world is therefore nothing more than a call for the globalization of policies and practices which are already evident, and which have been unearthed in locations throughout the capitalist world." (Foster, 2002: 63).

How can be the reactions to these arguments to protect the environment? As economic integration broadens and deepens, the scope of demands that citizens feel should be encompassed within the set of baseline standards grows. The process of parallel economic and political integration will not always be smooth. However, creating a sense of community will be necessary if countries wish to deepen their economic ties. This dynamic may create tensions as some countries, particularly those in the developing world, may have an expectation of complete national sovereignty in setting their own environmental standards. But the idea that environmental policy can be made in a political vacuum and be immune from external pressures misunderstands the imperatives of deepening economic integration. At the same time, developed nations which believe that their moral preferences should be accepted by others without question will find themselves facing a major backlash. In sum, absent a solid political foundation, including agreement on how to address shared environmental challenges, the drive for economic integration will falter. (Esty and Ivanova, 2005: 3)

\section{Minimizing the Negative Impacts}

Economic theory contends that the free market can be expected to produce an efficient and welfareenhancing level of resource use, production, consumption, and environmental protection if the prices of resources, goods, and services capture all of the social costs and benefits of their use. However, when private costs, which are the basis for market decisions, deviate from social costs, a "market failure" will occur resulting in allocative inefficiency as well as suboptimal resource use and pollution levels. Intensified international trade and the competitiveness pressures it can generate wield deleterious impacts on environmental quality, as market failures are a hallmark of the environmental domain. Many critical resources such as water, timber, oil, fish, coal, etc. are under priced. Ecosystem services such as flood 
prevention, water retention, carbon sequestration, and oxygen provision often go entirely unpriced. Because under priced and unpriced resources are overexploited, economic actors are able to spill onto others all or part of the environmental costs they generate and environmental strains are exacerbated.

Another (and related) concern is that globalization and freer trade will lead to competitive pressures that will push down environmental standards. A regulatory "race toward the bottom" might occur as jurisdictions with high environmental standards relax their regulations to avoid burdening national industries with pollution control costs higher than competitors operating in low-standard jurisdictions. While there is little evidence that standards are dropping, the real concern is not about a literal race to the bottom. Rather, the concern arises from the possibility that economic integration will create a regulatory dynamic in which standards are set strategically with an eye on the pollution control burdens in competing jurisdictions. The result may be a 'political drag' that translates into suboptimal environmental standards at least in some jurisdictions. These effects might involve not only weakened environmental laws, but perhaps more importantly, lax enforcement of existing rules, or standards not strengthened as much as they would have been.

From a global perspective, international trade increases the environmental burden when domestic differences in environmental policies exist. Environmental regulation raises production costs and this may reduce the market share of domestic companies in global markets. "Under a system of free trade, industries confronted with a strict environmental policy are then less competitive than industries which do not require environmental cost internalization. The industries in the non-internalizing country will increase their share of world output at the expense of the industries in the internalizing country." (Groot and Nijkamp, 1999: 340). This situation is placed in the literature as 'eco-dumping' (Ulph, 1996: 265) concept; lower environmental standards for lower production costs in developing countries to gain advantage for their firms in international trade. Consequently, "free international trade encourages dirty industries to shift their production activities to the countries that have the lowest standards of cost internalization-hardly a move toward global efficiency." (Daly, 1993: 52).

Diversity in circumstances generally makes uniform standards less attractive than standards tailored to the heterogeneous conditions that exist but not always. Divergent standards across jurisdictions may impose transaction costs on traded goods that exceed any benefits obtained by allowing each jurisdiction to maintain its own requirements. Upward harmonization (a "race to the top") may also occur. But this logic only applies to product standards.

Standards that relate to production processes or methods are not subject to the same market pressures. Yet, how things are produced matters. Production-related externalities cannot be overlooked. For example, semiconductors manufactured using chlorofluorocarbons contribute to the destruction of the ozone layer. Where international environmental agreements are in place, as with the Montreal Protocol on the protection of the ozone layer, trade rules should be interpreted to reinforce the agreed-upon standards. Recreated trade principles that accept the legitimacy of environmental rules aimed at transboundary externalities would make global-scale trade and environmental policies more mutually reinforcing and reduce the risk of the trade regime providing cover for those shirking their share of global environmental responsibilities. (Esty and Ivanova, 2005: 6).

\section{Maximizing the Positive Impacts}

Economic growth affects the quality of environment in different channels; scale effects, technological effects, composition effects and income effects. Increasing output requires more input and thus more natural resources are used up in production process. More output also implies more wastes and emissions as by-product, which also contributes to degrade environmental quality. Economic growth, thus, exhibits a scale effect that has a negative impact on environment. However, economic growth has a positive impact on environment through a composition effect: As income grows, structure of the economy tends to change 
and gradually increases cleaner activities that produce less pollution. Environmental degradation tends to increase as structure of the economy changes from rural to urban or agricultural to industrial, but it starts to fall with another structural change from energy intensive industry to services and knowledge based technology-intensive industry. As a wealthy nation can afford to spend more on R\&D technological progress occurs with economic growth and the dirty and obsolete technologies are replaced by upgraded new and cleaner technology, which improves environmental quality. This is the technique effect of economic growth (Dinda, 2004: 435). Income or wealth effects appear when greater financial capacity results in more resources being invested in environmental protection and creates demands for greater attention to environmental quality.

If the technique, income, and composition effects overwhelm the negative scale effect of expanded activity, then the overarching impact will be positive. For some issues and some levels of development the gains seem to outweigh the losses. For example, free trade appears to lower sulfur-dioxide concentrations. Income effects in this case outweigh scale effects. As a recent study by Antweiler, Copeland, and Taylor (2004) show that, a 1-percent increase in the scale of economic activity raises pollution concentrations by 0.25 to 0.5 percent but the accompanying increase in income drives concentrations down by $1.25-1.5$ percent via a technique effect. However, it appears that expanded trade and economic activity may worsen environmental conditions in other cases. Regional and global environmental harms, for example, exhibit positive correlation with rising incomes. When harms can be spilled onto other countries or the commons, there is little incentive to pay the costs of abatement since much of the benefit will accrue to citizens in other jurisdictions. Economic integration has broader economic and social impacts. Increasing interdependence often leads to a sense of community that builds a foundation of shared values and gives citizens a basis for demanding that others with whom they trade meet certain baseline moral standards, including a commitment to environmental stewardship.

\section{Environmental Kuznets Curve}

Corresponding to the early stage of economic growth, the awareness of environmental problems is low or negligible and environment friendly technologies are not available. Environmental degradation increases with growing income up to a threshold level beyond which environmental quality improves with higher income per capita. This relationship can be shown by an inverted-U-shaped curve (Dinda, 2004: 434).

Looking at the data across countries or across time allows some rough generalization as to the usual outcome of these conflicting effects. For some important environmental measures, an inverted U-shaped relationship appears: at relatively low levels of income per capita, growth leads to greater environmental damage, until it levels off at an intermediate level of income, after which further growth leads to improvements in the environment. This empirical relationship is known as the Environmental Kuznets Curve. The label is by analogy with the original Kuznets Curve, which was an inverted U-shaped relationship between average income and inequality.

The idea behind the Environmental Kuznets Curve is that growth is bad for air and water pollution at the initial stages of industrialization, but later on it reduces pollution, as countries become rich enough to pay to clean up their environments. The dominant theoretical explanation is that production technology makes some pollution inevitable, but that demand for environmental quality rises with income. The standard rationale is thus that, at higher levels of income per capita, growth raises the public's demand for environmental quality, which can translate into environmental regulation. Environmental regulation, if effective, then translates into a cleaner environment (Frankel, 2004: 9). However, not only the phrase that globalization increases income, but also the phrase that higher income generates more demand for better environment is questionable. It is important to recognize that many aspects of environmental quality are public goods. In order to be effective politically, demand for environmental quality must be articulated through institutions that overcome both free-rider problem and political opposition from the gainers of cost externalization. 


\section{The Effects of Environment on the Globalization}

Just as environmental protection efforts will be shaped by the path of globalization, environmental choices may affect the course of globalization, particularly efforts to liberalize trade and investment flows. At one extreme, a rigid harmonization of policy approaches and regulatory standards could run roughshod over the diversity of environmental circumstances, endowments, and preferences. At the other extreme, uncoordinated national environmental policies might become non-tariff barriers to trade that obstruct efforts to open markets. Deeper economic integration makes countries more sensitive to the regulatory choices and social policies of their trade partners. In the 1970s, when China's trade with the United States totaled less than $\$ 1$ billion a year, few US citizens cared about China's labor or environmental policies. Today, as China emerges as a major trade partner and competitor - and US-China trade has increased almost 100 -fold to $\$ 92$ billion in 2002 - these choices seem much starker. Thus, a key focus of trade policymaking centers on non-tariff barriers to trade and the need for a "level" playing field in the global marketplace (Esty and Ivanova, 2005: 7).

\section{Managing the process of globalization to protect the Environment and enhance sustainability}

Too much attention has been paid to the economic benefits of globalization and not enough to the social and environmental implications. As a result, the promise and potential of globalization as a force of sustainable human development may not be realized. Furthermore, at the same time that globalization attempts to improve the prospects for economic growth world wide; it may reduce the economic prospects in individual countries, sectors and communities.

To the extent that globalization marginalizes economies, sectors, and people, it results in poverty-induced resource depletion and environmental degradation, which lead to further human deprivation, disparity and dispowerment. The environmental consequences of globalization differ from the economic effects both in time and space: firstly, environmental impacts are more long-term, dynamic and cumulative and they are beset with uncertainty; we don't really know what the long-term damages are; secondly, environmental impacts involve both physical and non-physical spillovers that may or may not be transmitted through markets such as cross-border pollution, aesthetics, ethical or moral concerns of parties not involved in the transaction.

Globalization generates international interest in what traditionally were considered purely domestic policies, since economic integration implies that trade and investments are now being affected by such policies. Globalization increasingly brings into conflict notions of national sovereignty over production processes with globally-oriented life-cycle perspectives, where consumers want to know the overall environmental impact of what they buy and consume. These needs constrain national government capacities to regulate and necessitate intergovernmental coordination of domestic policies as well as cooperation in the management of the global commons. Without effective internationalscale governance, globalization may intensify environmental harms wherever regulatory structures are inadequate (Esty and Ivanova, 2005: 3). Thus, it becomes impossible to prevent the world's environmental crisis from getting progressively worse unless root problems of production, distribution, technology and growth are dealt with on a global scale (Kaplan, 1997: 26); national governments both cannot constrain the pollutions within their borders and impede the entrance of other countries' pollution into their borders.

\section{Conclusion}

The effects of globalization on the environment and the environment on the globalization are multidimensional. It is not easy to determine the whole impacts. Globalization may sustain the economical growth as well as increasing of income. On the other hand, respecting to the globalization, the pollution increases due to the fact that the production volumes are rising. The pollution causes the environment to be damaged and in some cases not easy to overcome with the results. 
In this paper I investigated the interrelationship between the globalization and the environment in an economic perspective. I discussed both positive and negative impacts of globalization on the environmental issues after giving brief information about the economic meaning of the globalization. As a result, I think we can derive some suggestions to national governments about the process of managing the globalization to protect the environment and enhance sustainability. These may include: accelerating democratization and institutional development to keep in pace with globalization, reforming domestic policies that both distort trade and have negative environmental impacts (e.g. energy subsidies), correcting existing market failures though efficient incentive systems (economic instruments) that internalize environmental costs, to avert their magnification by trade liberalization and economic integration, improving the effectiveness of environmental policy through the involvement of businesses and local communities in monitoring and enforcement rather than relying on the state's limited budget and weak regulatory enforcement capacity. "Instruments of empowerment include information disclosure in environmental performance of firms, and provision of training and other capacity building services to communities." (Panayotou, 2000: 36).

Economic instruments can be summarized as; to support the producers with subsidies to give incentives for making use of the more environment friendly production techniques, to impose quotas on the production of the polluting industries, to set standards in the production process about the environmental quality, to ban the polluting activities legally or to give penalties to those activities, to support the firms for adopting the environmental standards, to privatize of environmental public goods if they cannot be secured because of their public good nature. However, we should notice that the aim is not to reduce pollution damages to zero but reduce them to socially optimal levels. This implies there will always be some level of pollution. This optimal level is obtained where the marginal social benefit of the decreasing of the pollution equals the marginal social costs of the efforts to reduce pollution.

\section{References}

Alauddin, M. (2004). Environmentalising Economic Development: A South Asian Perspective, Ecological Economics, 54, 251-255.

Antweiler, W., Copeland, B.R. and Taylor, M.S. (2001). Is Free Trade Good for the Environment? American Economic Review, 91(4), 877-908.

Boyce, J. K. (2004). Green and Brown Globalization and the Environment. Oxford Review of Economic Policy, 20(1), 105-128.

Christmann, P. and Taylor, G. (2002). Globalization and the environment: Strategies for international voluntary environmental initiatives. Academy of Management Executive, 16(3), 121-135.

Çınar, Ö. M. (2003). Sürdürülebilir Kalkınma ve Çevre, (Unpublished M.A. Thesis), Yıldız Technical University, İstanbul, Turkey.

Daly, H. (1993). The Perils of Free Trade. Scientific American, 269(5), 50-57.

Dinda, S. (2004). Environmental Kuznets Curve Hypothesis: A Survey Economic Research Unit, Indian Statistical Institute, India

Dura, C. (1991). Çevre Sorunları ve Ekonomi. In Fisunoğlu, M., Dura, C. and Bilge, R. (Eds.), Çevre ve Ekonomi, Ankara, Turkey: TÇSVY Publications

Ehrenfeld, D. (2003). Globalization: Effects on Biodiversity, Environment and Society. Conservation and Society, 1(1), 99-111.

Esty, D. C. and Ivanova, M. H. 2005. Globalization and Environmental Protection: A Global Governance Perspective. In Wijen, F. (Eds.) A Handbook of Globalisation and Environmental Policy. London, U.K.: Edward Elgar Publishing.

Fischer, S. (2003). Globalization and its Challenges. American Economic Review, 93(2), 1-30.

Foster, J. B. (2002). Ecology against Capitalism, New York, monthly review press.

Frankel, J. A. (2004). The Environment and globalization. (Unpublished M.A. Thesis), Harvard University Kennedy School of Government, Cambridge: U.K.

Groot, D. V. and Nijkamp, P. (1999). Globalization, Transport and the Environment: New Perspective for Ecological Economics. Ecological Economics, 31(3), 331-346. 
Hodge, I. (1995). Environmental Economics: Individual Incentives and Public Choices, London, U.K.: Macmillan.

Hussen, A. M. (2004). Principles of Environmental Economics, New York, U.S.: Routledge

Kaplan, A. (1997). Küresel Çevre Sorunları ve Politikaları, Ankara, Turkey: Mülkiyeliler Birliği Yayınları Mabogunje, A. L. (2002). Poverty and Environmental Degradation, Environment, 44(1), 8-18.

OECD, (1984). Environment and Economics: Results of the International Conference on Environment and Economics, Organization for Economic Co-operation and Development, Washington D.C.

Panayotou, T. (2000). Globalization and Environment. Environment and Development Paper No.1 CID Working Paper No. 53 Center For International Development At Harvard University

Repetto R. (1991). Accounting for Environmental Assets. Scientific American, 266(6), 94-100.

Salahuddin, A. (2005). Globalization and Environmental Management Education in Developing Countries, The Cost and Management, National University, Gazipur, Bangladesh

Sisay A. (2005). The Economics of Sustainable Development, Upjohn Institute for Employment Research.

The World Bank, (1997). Environmentally Sustainable Development Studies and Monograph Series No.17, Expanding the Measure of Wealth: Indicators of Environmentally Sustainable Development. The World Bank, Washington D.C.

Ulph, A. (1996). Environmental Policy and International Trade When Governments and Producers act Strategically, Journal of Environmental Economics and Management, 30, 265-281.
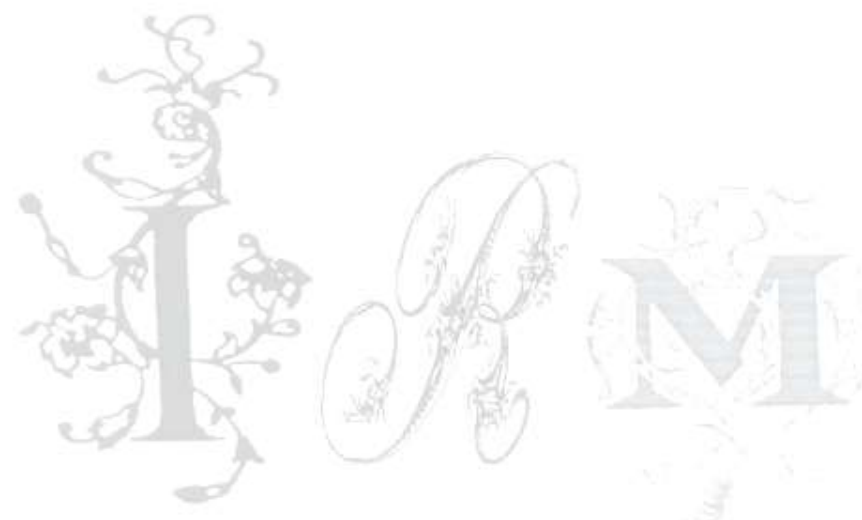